\title{
The Evolution of Globalism: From Computerization to e-Democracy and the Digital Economy of Knowledge
}

\author{
A. P. Lyubimov, * and V. V. Cherny ${ }^{b, c, d, * *}$ \\ ${ }^{a}$ Presidium of the Russian Academy of Sciences, Moscow, 119991 Russia \\ ${ }^{b}$ Fund for the Protection of the Constitutional Rights of the Indigenous Minorities of Russia, Moscow, 125130 Russia \\ ${ }^{c}$ Board of the Russian Agency for the Development of the Information Society, Moscow, 109012 Russia \\ ${ }^{d}$ Union of Journalists of Russia, Moscow, 119021 Russia \\ *e-mail: aplyubimov@presidium.ras.ru \\ **e-mail: chernyv@list.ru \\ Received November 19, 2020
}

\begin{abstract}
This paper deals with current problems of computerization, e-democracy, and the digital economy of knowledge. Global trends in the digital information society, e-democracy, and the economy of knowledge form the agenda of modern development. New opportunities for development in the information society have shown that virtuality contributes to the emergence of unconventional reality, which can also give rise to new threats and crises. Scenarios are discussed where the economy, science, high technology innovation, culture, and everyday life change under the influence of virtuality.
\end{abstract}

Keywords: electronic democracy, digital economy, knowledge economy, national security, globalization, innovations, information society, civil society

DOI: $10.3103 / \mathrm{S} 0005105521020060$

\section{INTRODUCTION}

Various sectors of the economy increasingly employ contemporary high technologies and systems, of which there are multiple examples ${ }^{1}$. At the beginning of the popular essay book Where Is Humanity Going? On the Tendencies of International Relations in

\footnotetext{
${ }^{1}$ Lyubimov, A.P., From information, information processes, and technologies to nanotechnologies. Interview with the Nobel laureate, deputy of the State Duma, Academician and Vice President of the Russian Academy of Sciences Zh.I. Alferov, Predstavitel'naya Vlast' - XXI Vek, 2009, no. 4, pp. 1-5; Lyubimov, A.P., Formation of the national concept of the innovation system of Russia (part 1), Predstavitel'naya Vlast' - XXI Vek, 2011, nos. 7-8, pp. 24-29; (part 2), Predstavitel'naya Vlast' XXI Vek, 2012, nos. 2-3, pp. 9-14; Lyubimov, A.P., Fundamentals of e-democracy in Russia, in Aktual'nye voprosy ekonomiki, upravleniya i prava: Sbornik nauchnykh trudov (Yezhegodnik) (Current Problems of Economics, Management, and Law: Scientific Papers (Yearbook)), Moscow: MGUKI, 2013, pp. 5-11; Lyubimov, A.P. and Cherny, V.V., Anti-crisis economy and decriminalization of bankruptcy, Predstavitel'naya Vlast' - XXI Vek, 2019, no. 3, pp. 17-21; Cherny, V.V., Tsykalo, V.V., and Alyaev, A.V., Russia and international security of the third millennium, Observer, 2004, no. 5, pp. 27-35; Cherny, V.V., Security of Russia lies in the development of an innovative economy, Observer, 2009, no. 7, pp. 53-59; Cherny, V.V., Intellectual revolution and Russia, Strategiya Ross., 2009, no. 7, pp. 29-32; Cherny, V.V., Science and global democracy: The role of Russia, Mir Polit., 2009, no. 11, pp. 101-109; Cherny, V.V., Globalization of democracy: Civil society and security, Diplomaticheskaya Sluzhba, 2011, no. 5, pp. 12-20.
}

the 21st Century [1], E.P. Bazhanov and N.E. Bazhanova refer to the Chinese wisdom that "it is difficult to predict, especially the future," and then they argue that "the future is generally unpredictable." Then, both in the text of the book and in articles [2,3], their position softens and the authors agree with that Chinese wisdom. Indeed, major events of the 20th-21st centuries support the validity of both these pessimistic conclusions. As historical experience shows, forecasts of the ways of human development, as a rule, are not very accurate. Nevertheless, it is necessary to try to determine the trends in the development of humankind, at least in the short term, based on analysis of processes that occur on the planet, and then consider the possibilities of economic development for modern Russia.

We live in an era of rapid strengthening of interconnections and interdependences of states. This trend has been called "globalization" [3]. Fundamental science is advancing at high rates, the scientific and technological revolution is accelerating in the modernization of means of transport, in information technology and communications, nanoelectronics and biomedicine, space research, and many other areas. The process of globalization of democracy is changing the picture of the modern world [4-16]. Today, humanity is moving into the state of the global information society [10-14]. A new phenomenon is being observed: glo- 
balization is cyclical and is accompanied by periodic financial and economic crises.

\section{ELECTRONIC DEMOCRACY AND DIGITAL DIPLOMACY}

The computerization of society and the invention of the Internet have already led to the actual emergence of electronic democracy [7]. This is evidenced by the numerous tools of the Internet to access the global information society, which are available to everyone. However, states are still the main players in the international arena ${ }^{2}$. The Internetization of the world space and the liberalization of finance make the borders of states virtually transparent ${ }^{3}$. Digital diplomacy is becoming a soft power tool for promoting foreign policy views and influencing public opinion. The leaders of countries are constantly calling for more intensive use of new technologies on various platforms, including social media, to communicate the position of the state. At the same time, intellectual resources, initiatives of civil society and individuals, can influence the trends of economic development of countries and the entire system of international relations [14-18]. In the information society, new opportunities have shown that virtuality contributes to the emergence of an unconventional reality that gives rise to new threats and crises [5, 17] For each country to exist and for all the humankind to survive, it becomes necessary to construct an effective system to counter novel challenges and threats ${ }^{4}$.

Global trends in the formation of the information society and e-democracy form the agenda of modern development. Today, the world press is increasingly frightening the general public with the moral decline of modern democracies and the degradation of political systems on entire continents. They write with pessimism about the chaos and crisis of the global economy at the very center of its liberal core and about the unfulfilled hopes of beneficial advancement of market principles around the world. Almost hysterically, the media talk about the increased turbulence in international relations. With caution, the media mention the growth of social unrest and even about the possible collapse of global capitalism in the form represented to us by modern theorists of the "new digital economy."

\footnotetext{
${ }^{2}$ Cherny, V.V., Globalization of democracy: Intellectual revolution of the information society and the dark matter of global finance, Predstavitel'naya Vlast'-XXI Vek, 2012, nos. 2-3, pp. 63-66; Predstavitel'naya Vlast' - XXI Vek, 2012, no. 4, pp. 33-37; Predstavitel'naya Vlast' - XXI Vek, nos. 5-6, pp. 48-52; Cherny, V.V., UN Permanent Forum on the Rights of Indigenous Peoples 2019, Predstavitel'naya Vlast' - XXI Vek, 2019, no. 4, pp. 14-16.

${ }^{3}$ Cherny, V.V., Security of Russia lies in the development of an innovative economy, Observer, 2009, no. 7, pp. 53-59; Cherny, V.V., Intellectual revolution and Russia, Strategiya Ross., 2009, no. 7, pp. 29-32.

${ }^{4}$ Cherny, V.V., in UNPFII Eleventh Session, New York: UN, 2012, item 8.
}

Multiple scientific conferences discuss either the unexpected arrival of the long crisis "Kondratyev cycles" or the slipping of the early instances of "smart commerce." Frightening theories of "diminishing economy" are suggested. There is fueling of the ageold struggle between adherents of the economic theories of Keynes and Friedman, who traditionally either refine models of stimulating demand or propose novel, ingenious ways for outstripping production supply and proactive investment.

In the complex interweaving of the proposed theories, it is necessary to analyze and understand how they all explain the reasons for the current stage of development of human society. At the same time, it is necessary to reveal what will be more important in the upcoming development: information strengthening of the market or the clogging of its respiratory pores by the already obvious information pollution of the environment? Let us also try to determine the reason that the world economy, barely having time to cheer up after financial bubbles burst, immediately got bogged down in the newly formed crisis, why the main locomotives for breakthroughs stall on the sidetracks, and how can the situation be corrected for a crisis-free movement? To the end, it is necessary to get a feel of the trends in the management system of a developing democracy.

Today, it is clear that the experience of introducing a liberal economy in Russia in the 1990s with its reforms and privatization was economically ineffective. After privatization, enterprises systematically became unprofitable, workers lost their jobs, and the population became impoverished. The demanded products were not allowed to Europe: they had their own standards and high competition. The country began to live off cash and commodity loans, which in such cases were given by the West. Debts were paid off with interest. The development of the country became problematic; it lived according to the laws of the economy of peripheral capitalism. Experience shows that economic liberalization always comes at the expense of the poor. Since the government is responsible for Western loans and not for the people, the country loses its state independence. To get out of this situation, it is necessary to choose foreign partners with which cooperation will comply with national interests. The domestic economy should promote the entrepreneurial initiative of the population and public-private partnerships.

In our concept, we proceed from certain milestones in the history of human development, which played a crucial role in changing life on the planet. We take the agrarian and industrial revolutions, the computer revolution, and the Internet revolution associated with the intellectual revolution of the information society as our starting points. By the term "revolution" we mean a radical change in the technological order, economy, and social life. Even today, one can identify 
the poles of development: virtuality, on the one hand, has changed science and industry, and on the other hand, it penetrated deeply into the sphere of politics and even predetermined hybrid wars. We are witnessing an avalanche-like "smartening" phenomenon, the independent intellectual development of entire areas of creative activity and hi-tech.

The modern interpretation of the concept of democracy is often considered somewhat vague, but nevertheless it rests on three pillars: human rights, open global community and an open global market, and civilian control of weapons. This is the opinion of researchers, at least those from the countries that more or less successfully promote democracy in the international arena. The process of democratic transformations in the world is complex; it is widely discussed and deserves separate consideration. Without dwelling on this, let us note a very important general aspect of democratic transformations: today it is necessary to consider rapid changes in the world associated with the introduction of scientific advances and high technologies to the life of the planet. Therefore, the new definition of the concept of democracy should include this role as one more, fourth pillar: "science and high technologies for international security and cooperation of countries" [6]. This will allow humanity to avoid pessimistic scenarios of the "end of history," "clash of civilizations," and others. In the era of e-democracy and the knowledge economy, the developing world democracy cannot survive without the salvatory voice of science and high technology.

\section{GLOBALIZATION OF INDIVIDUAL PRIVATE PARTICIPANTS}

Without delving into the intricacies of strengthening the military power of countries and geopolitical problems, it is important for our analysis to identify the main drivers of economic growth in people's lives and understand their place in the trends of modern planetary development. Inequality in the economic development of countries leads to the loss of scientific and technological sovereignty, complicates international relations, weakens international and national security, and requires special attention to ensuring military security, which boosts the costs of strengthening the defense capabilities.

We are seeing how a private initiative in information and communications technologies and microand nano-technologies in Silicon Valley nurtured and shaped the second generation of private space exploration: SpaceX and Virgin Galactic. For the 55th anniversary of manned space flight, Russian businessman Y. Milner allocated $\$ 100$ million to NASA AMES Research Center for the Breakthrough Starshot project intended for research of deep space and search for life in the vicinity of the Alpha Centauri star based on F. Zander's (1926) idea of a method for interstellar travel. A project is being developed to land an unmanned Dragonfly on Titan, a satellite of Saturn. On October 21, 2020, the NASA OSIRIS-REx space probe automatically hovered at an altitude of $3.5 \mathrm{~m}$ above the Bennu asteroid, extended the robotic arm, and collected surface samples, and it should return to Earth in September 2021. To understand the brilliance of this experiment, one needs to know that the radio signal from the Earth to the asteroid takes $18 \mathrm{~min}$. In 2021, in addition to the Hubble Orbital Telescope that has been operating for 30 years, NASA will launch the Webb Orbiting Telescope. A robot will assemble its mirror with diameter of $5.6 \mathrm{~m}$ directly in orbit from separate segments. Together with 263 ground-based telescopes and the largest telescope in Chile (with a mirror diameter of $39 \mathrm{~m}$ ), the entire system will not only explore space for 13 billion light years in depth but also ensure the space safety of the Earth. The Kurchatov Institute Research Center implements the concepts of the so-called convergent NBICS technologies that combine nano-, bio-, information, cognitive, and socio-humanitarian technologies, as well as those hybrid high-tech industries that have been transformed by the virtual change of the world.

This means an influx of intellectual forces from all over the world, which leads us to talk about the globalization of democracy in the scientific field. This process has penetrated into manufacturing, improving many approaches to the realization of natural human rights in a free creative scientific search and in a new individualized-private social organization of labor.

All this allowed individuals to more widely implement their own ideas and give freedom to scientists to achieve a state of comfortable existence. The particularly successful Intel, Microsoft, Apple, and SpaceX are useful examples here, but there are many more. All of them started with small forms of individual private entrepreneurship; today they have become business giants that determine the level of civilization development on the entire planet. They emerged as a product of the development of a culture of human activity in the field of science and high technologies, liberalization of finance, and improvement of creative abilities for the further advancement of individual creativity.

The innovators' initiative, supported by the state, has repeatedly led to new technological realities that changed the lives of people on the planet, to different architectures of the financial and economic systems, to improvement in the social organization of labor and, in fact, to new technological paradigms. These were the inventors of the steam engine I. Polzunov and J. Watt, the creators of the steam locomotive G. Stephenson and $\mathrm{M}$. Cherepanov, the inventors of the radio communication A. Popov and G. Marconi, the creators of the point-contact transistor W. Shockley, G. Moore, and R. Noyce, Intel founder E. Grove, Apple founder S. Jobs, Microsoft creator B. Gates, Facebook founder M. Zuckerberg, Google founder S. Brin, private astronautics pioneer E. Musk, founder 
of 400 companies within the Virgin Group R. Branson, research physicists P. Kapitsa, L. Landau, A. Abrikosov, V. Ginzburg, N. Basov, A. Prokhorov, M. Keldysh, A. Alexandrov, E. Velikhov, Zh. Alferov, Yu. Gulyaev, and M. Kovalchuk, mathematicians V. Sadovnichy and G. Perelman, research chemists, biologists, physicians, and others.

An important point for the state here is to competently track the priority development trends and their timely introduction into the practice of innovations. From the experience of the United States, we see a well-organized stage of support for small business entities, which is incorporated into the practices of the aforementioned tech giants. They are effectively reproduced by affiliates all over the world. For the convenience of launching and implementing projects, "swarms" of small firms working for large enterprises are created according to the scheme of the so-called local bandit companies. This contributes to the preservation of the intellectual property of innovators and significantly increases the effectiveness of their creative work. Western universities and firms painstakingly collect talented scientists and promising developments around the world. Universities organize funds (endowments) to support science and education, which exist at the expense of tax-free donations from oligarchs and corporations. By the way, these funds are engaged in the selection of young talents in other countries as well, very successfully carrying out external commercial activities and increasing their capital.

The experience of new technologies is not always successful economically. However, to try to start something is a property, as they say, of "creators of their own happiness." Thus, the Nobel laureate W. Shockley, who received an award for inventing the transistor, which marked the birth of the microelectronic era, understood the importance of commercializing his discovery. He founded a firm but went bankrupt. However, the business he started survived. His colleague $\mathrm{G}$. Teal was more fortunate, he found a way to reduce the price though mass production of transistors and so became successful.

There are many similar examples. Most developed and developing countries dream of repeating the successful experience of this technological renaissance. Therefore, according to many researchers, this example of the information revolution has already launched the process of an intellectual revolution with a fantastic use of information technologies available to everyone [9-15]. This phenomenon can be referred to as the knowledge economy ${ }^{5}$. In education, it helped to find a new paradigm of meanings and such phenomena as "smart technologies," "smart economy," and

\footnotetext{
${ }^{5}$ Cherny, V.V., Volkov, K.A., Esayan, L.R., and Dybov, V.A., Grazhdanskoe obshchestvo v Rossii. Biznes $i$ bezopasnost' (Civil Society in Russia. Business and Security), Moscow: SAIBR, 2006.
}

other avalanche-like "smartening" of entire areas of creative activity and hi-tech. What is happening, as before, is reflected in new forms of social organization of labor and newly created instruments of global finance, among which some economists distinguish the area of "dark matter of the economy and global finance" [3, 16, 19]. This last phenomenon is apparently due to the fact that the markets for public and corporate securities, derivatives, futures, options, forwards, interest rate swaps, and others are moving or have already moved into the area of global deferred debts, which, figuratively speaking, are getting into the pockets of future generations of humankind. Obviously, our descendants will have to pay for this. It is especially true of the American economy, with its bloated volume of debts to the whole world amounting to $\$ 26$ trillion (as of June 12, 2020).

If we believe that the main characteristic of the modern intellectual economy is the "small-parameter civilization," the so-called global conglomerate of single handicraftsmen capitalizing their intellectual capital into the future, it should be noted that this capital requires development, including outside of any state borders. Consequently, the debts of even the most intellectual part of the corporations of the United States (that is, the debts of innovators borrowing from other subjects of global civilization) will have to be paid out not only by possible bankruptcies but also by the rest of humanity, if the next financial bubbles of such projects continue to be created.

With the deepening specialization and division of modern labor, with the division into advanced individuals and other lagging industrial world (represented by traditional forges like China and the Asian Tigers), new individuals, in principle, can unite into trade unions, and trade unions into communities. However, these will be qualitatively new communities. The predominant source of wealth creation will be represented by information and increased actualization of the process of implementing new knowledge. Intelligence is becoming the most demanded commodity due to its ability to generate super-profit. Since information in such a system is capable of generating wealth, only those individuals who identify and solve new problems will become successful.

\section{GLOBALIZATION OF DEVELOPMENT DEMOCRACY}

The process of the political and economic transformations that we described is accompanied by the globalization of democratic principles $[3,14,16]$. This is happening on the basis of the improving culture of information assimilation by individuals, the increasing total volume of knowledge, and liberalization of information and financial instruments of emerging markets. Naturally, the "small-parameter economy" helps here: that same small business that encouraged people to exercise their freedom of self-expression through an 
intellectual resource in conjunction with entrepreneurship. At the same time, the state, under the auspices of a strong system of education and science, strengthens the sovereignty and security of the systems that are created, and stimulates their survival.

Starting with the intellectual "newcomers," the process of migration of scientists and high-tech specialists across countries gave rise to new problems. Politicians are trying to take advantage of this circumstance to solve their own geopolitical problems. The stirring dark forces of capital are taking advantage of the international division of labor and globalization to use the cheapest labor. On the one hand, this has revived China as a world consumer goods factory, which saturated countries with cheap goods. However, at the same time, it made it possible to turn a blind eye to noncompliance with the norms of civilized labor legislation. The culture of relations in this context began to be seen as a global social movement renewed by virtuality, which led to powerful tectonic shifts. The rich get richer both in individual countries and across continents. The poverty gap began to widen at alarming rates, threatening social tensions. This inevitably leads to the redistribution of capital, its concentration, and creates the prerequisites for new waves of socioeconomic crises.

The situation that has arisen requires new creative, nonstandard solutions. Unfortunately, in the commotion of expert opinions, it is not yet possible to outline a clear strategy for Russia for restructuring its economy and to elaborate the details of innovative transformations. In practice, forecasts are not very correct. For such an "unstable equilibrium," for our inability to command forms of intellectual (and simply effectively working) property suitable for technological breakthroughs, we have to pay with financial and economic losses.

\section{DIGITAL ECONOMY OF KNOWLEDGE}

Now the question arises: do we clearly see (especially under the conditions of Western sanctions for Russia) cloudless pictures of our harmonious development? Alas, it must be admitted that we are not far from the definition given by the classic thinker, V.I. Lenin, who bequeathed us to learn, learn, and learn... Although, to quote it accurately, this phrase has an important continuation and recommendation: "to learn trading from capitalists." This must be remembered in order not to repeat instances such as when Russia basically "donated" 500 tons of weapons-grade uranium to be used as fuel at American nuclear power plants in 1993. However, one must learn not only the trade but also well-thought-out long-term competition in all areas of economic priorities, both high-tech ones, which form the level of civilizational development, and humanitarian ones, which determine the ideology of the country's development vector.
The same applies to the not entirely clear situation with the decision to preliminary publish materials of dissertations, with the hope of possible cooperation with the external high-tech world. In a tough fight against plagiarism, after nationwide reading in open access and discussion of the discoveries and scientific achievements contained in these materials, the commercial attractiveness of the intellectual property of the research is lost. Everything that is newly published, when intellectual property is not properly protected, is instantly requisitioned by experienced competitors in the global race for scientific discoveries and so becomes obsolete. It turns out that sometimes we turn our science and technology into an intellectual donor for economically successful countries.

It is known that science and scientific discoveries are the driving force of progress. Scientific discoveries determine the imperial power of the state in the international arena. It is said that "in science there is nothing more practical than a good theory," however, "in science something is solid only when it is introduced into practice." Therefore, it is necessary to competently commercialize scientific results in order to generate profit, compensate for the costs of scientific research, and establish manufacturing of a new product. The same applies to the scientific and technological achievements of the military-industrial complex (MIC). Thus far, such commercialization is the "Achilles' heel" of Russia's economy. It is a very complicated problem, although an extremely important one. Theoretically, it is necessary to make an evolutionary transition from the provisions of the added value of A. Smith and K. Marx to the added value of modern national accounts. Practical experience of the successful transition to such commercialization can be borrowed from the United States and the leading economies of Europe. We must not forget that the first person in the world to pay attention to the commercialization of the knowledge and "intelligence" trade was Russian I.T. Pososhkov in his socio-economic treatise "The Book of Poverty and Wealth" of 1724, when A. Smith had just been born. For the successful implementation of the program for the commercialization of scientific achievements and the increase in the gross value added of high-tech products, as well as goods and services, Russia needs to improve the interaction of the defense industry complex, the Federal Protective Service, the Russian Academy of Sciences, the Ministry of Economic Development, the Ministry of Science, the Ministry of Industry and Trade, and other departments to the advanced level.

It is hard not to mention great M.V. Lomonosov, who in 1761 called us "to multiply our glory in the world, and higher than a military basis, to put forward the beauty of sciences." It would hardly be advisable to bring science and technology to a situation similar to the ever-memorable absurd campaign against alcoholism in the USSR in 1985-1987. It was the time when unique, collectible grape varieties were cut 
down, and today we are weakening the growth of thinned out scientific schools by sending talented young researchers and unique results of their creative work for export.

Not verbally in practice, it would be more effective to competently establish not only credit and investment policy but also borrowing in the economics and social organization of labor from the West, where they have already discovered, identified, and applied the terms of further development and the components of successful breakthroughs. In this situation, with the processes of globalization of democracy outlined here, we naturally need not only to protect our achievements but also to construct an innovation strategy according to the laws of the modern "information society," relying on the freedom of entrepreneurship and the multiplication of the main intellectual resource represented by human capital [8]. Such an approach will allow Russia to overcome the sanctions costs and successfully integrate into the global economy. The same applies to the regions of the country, which should become a continuation of such infrastructure hyperprojects as the new Vostochny cosmodrome and successful transformations in the military-industrial complex with the commercialization of innovative solutions, as well as other similar growth drivers that are still in short supply for mass use.

\section{PROBLEMS OF DIGITALIZATION} AND ARTIFICIAL INTELLIGENCE

Prime Minister of Russia M.V. Mishustin [19] believes that unregulated digitalization leads to the disappearance of entire sectors of the economy, along with enterprises and jobs. It changes social behavior of people, affects labor relations, and the attitude towards property. The tax base is being eroded, there are threats to the existence of regulators, including public and state institutions. Cash flows are disappearing as big digital companies become the owners of data as a commodity. A country where this value was created loses its profit. The state needs its own digital security system, an inventory of all technological capabilities, and creation of technology competence centers. In addition, e-democracy and the digital knowledge economy should contribute to solving complex social problems. Of course, the development of artificial intelligence also requires the development of natural intelligence. Education in the context of edemocracy and digital knowledge economy should form both deep-thinking professionals and citizens who are aware of their place in life and the processes taking place in the state and in the world, who are able to independently distinguish between good and evil without being affected by propaganda and can make progressive decisions.

Online communication taking place today due to the coronavirus pandemic can also change the paradigm of political processes. The previous form of par- liamentary and party institutions can take on a massive, public character with the transition to an informal exchange of views of specialists and listeners at videoconferences. The problem of confidentiality of citizen data and their privacy as the basis of human rights takes on a special role here.

Threats to the national security of Russia are mainly associated with the digitalization of the national economy according to Western recipes [20]. Therefore, it is required to develop a proactive artificial intelligence program implemented on a domestic technological platform [21]. There are forces in Russia that can implement an alternative strategy for constructing the future for the growth of public good, including with partner countries in the EAEU, which have unique experience in live input-output planning taking into account feedback and knowledge of economic cybernetics to calculate the trajectory towards the goal set, that is, constructing the future in the desired direction.

\section{CONCLUSIONS}

It is advisable to establish a system of proactive artificial intelligence [21] on the basis of dynamic inputoutput modeling that organizes information flows from economic objects to coordinate their activities towards the implementation of strategic goals and to accelerate the development through the introduction of new technological methods of production. It is necessary to create dynamic economic models that should reflect mechanisms of action and implementation of objective economic laws of development [22].

The "newer" the property is, the more civil the society is: this conclusion follows from the review of technological revolutions accompanying the virtual and intellectual development demonstrated by developed countries [14-17]. In Russia, especially in the level of its management and the elite, it is nevertheless necessary to raise awareness of fact that only through effective forms of property and a civilized market that a successful middle class can be formed, one that will also be socially active, acting as a working innovator and a generator of unique ideas. Support and protection of all forms of property, including intellectual property, requires development, and maybe even a qualitative leap in the legal consciousness of the entire society, which could renounce primitive, including oligarchic, ways of existence. In this respect, for example, Gazprom's offer to sell company's shares to everyone is interesting. However, implementation of such an idea requires a growing effective demand of the population.

A sound personal interest in the assimilation of high-tech industries and the entire high-tech field should grow and develop in society. This will take some real brainstorming on the part of the progressive part of the Russians. The world needs a scientifically 
and technologically strong Russia with a developed and diversified economy that meets the needs of the population. This has been established historically: the world is not complete without Russia.

\section{REFERENCES}

1. Bazhanov, E.P. and Bazhanova, N.E., Kuda idet chelovechestvo? O tendentsiyakh mezhdunarodnykh otnoshenii $v$ XXI veke (Where Is Humanity Going? Trends in International Relations in the 21st Century), Moscow: Vostok-Zapad, 2009.

2. Bazhanov, E.P., Russia and the West, Mezhdunar. Zhizn', 2013, no. 12, pp. 11-36.

3. Bazhanov, E.P., Globalization as an objective process, Ekho Planety, 2010, no. 32, p. 21.

4. Dobretsov, N.L., Zolotov, Yu.A., Ivanov, V.T., Leont'ev, L.I., Makarov, A.A., Myasoedov, B.F., Natochin, Yu.V., Ostrovskii, M.A., Rozanov, A.Yu., Ushachev, I.G., and Chernous'ko, F.L., Council of Elders of the Russian Academy of Sciences: Reform is a blow to Russian academic science. Measures to enhance the role of the Russian Academy of Sciences in the scientific and technological development of Russia, Predstavitel'naya Vlast' - XXI vek, 2020, nos. 1-2, pp. 12-20.

5. Smirnov, A.A., Obespechenie informatsionnoi bezopasnosti v usloviyakh virtualizatsii obshchestva: Opyt Evropeiskogo Soyuza (Information Security in the Context of the Virtualization of Society: Experience of the European Union), Moscow: YuNITI-DANA, 2011.

6. Cherny, V.V. and Kapkov, A.Yu., Russia and the USA: Virtual games of superpowers (the "end of history" is canceled, and "the clash of civilizations" lead to new models of democracy, international cooperation, and international security), Eur. Secur., 2000, vol. 9, no. 3, pp. 123-133.

7. Lyubimov, A.P., Administrative and legal basis of e-democracy, Predstavitel'naya Vlast' - XXI vek, 2012, no. 4, pp. $2-4$.

8. Lyubimov, A.P., Prospects for the creation of Russian innovation clusters, Predstavitel'naya Vlast' - XXI vek, 2013, nos. 5-6, pp. 14-19.

9. Lyubimov, A.P., On public control over computerized vote counting during elections, Zakonodatel'stvo, 1998, no. 11 , pp. $69-76$.

10. Babkin, V.V., Promonenkov, V.K., Ovcharenko, M.M., and Lyubimov, A.P., An innovative concept for plant protection products in the Russian Federation, Khim. Prom-st. Segodnya, 2017, no. 8, pp. 50-54.
11. Lyubimov, A.P., Basic approaches to defining "artificial intelligence," Nauchno-Tekh. Inf., Ser. 2, 2020, no. 9, pp. 1-6.

12. Lyubimov, A.P., Advantages and disadvantages of two important bills: Expert opinions. Round table in the State Duma, Zh. Ross. Prava, 2000, no. 4, pp. 26-27.

13. Lyubimov, A.P., Ponomareva, D.V., and Barabashev, A.G., On the question of the concept of artificial intelligence in Russian law, Aktual. Vopr. Ekon. Upr. Prava: Sb. Nauchn. Tr., 2019, nos. 2-3, pp. 16-34.

14. Lozhkovoi, P.N., The legal nature of the activities of states on remote sensing of the Earth from Space, $A k$ tual. Vopr. Ekon. Upr. Prava: Sb. Nauchn. Tr., 2018, no. 4, pp. 4-19.

15. Pronchev, G.B., Lyubimov, A.P., Proncheva, N.G., and Tretiakova, I.V., Social and economic causes of labor migration in contemporary Russia, Espacios, 2019, vol. 40 , no. 32, p. 13.

16. Kapkov, A.Yu. and Chernyi, V.V., Evolyutsiya globalizma: Ot kollektivnogo bessoznatel'nogo - $k$ kollektivnomu soznatel'nomu (The Evolution of Globalism: From the Collective Unconscious to the Collective Conscious), Moscow: Izd. S.P. Shukshinoi, 2014.

17. Pronchev, G.B., Mikhailov, A.P., Lyubimov, A.P., and Solovyev, A.A., Particularities of the Internet-based virtual social environments within the context of information warfare, Eurasian J. Biosci., 2020, vol. 14, pp. 3731-3739.

18. Shchitov, A.N., Project "Open Science of Russia," Aktual. Vopr. Ekon. Upr. Prava: Sb. Nauchn. Tr., 2020, nos. 2-3, pp. 77-86.

19. Mishustin, M.V., Formation of a sustainable region based on data and artificial intelligence, International Forum "Digital Future of the Global Economy" (January 31, 2020, Alma-Ata, Kazakhstan). http://government.ru/ news/38885/. Accessed November 10, 2020.

20. Veduta, E.N., Digital economy will lead to economic cyber system, Mezhdunar. Zhizn', no. 10, 2017, pp. 87102.

21. Veduta, E.N., Lyubimov, A.P., Dzhakubova, T.N., and Ryaskova, E.S., The concept of the national program for the creation of proactive artificial intelligence, Predstavitel'naya Vlast' - XXI Vek, 2019, no. 4, pp. 22-29.

22. Veduta, E.N., Strategiya i ekonomicheskaya politika gosudarstva (Strategy and Economic Policy of the State), Moscow: Akad. Prospekt, 2004.

Translated by K. Lazarev 